\title{
THE FIRST PRELIMINARY QUESTIONS TO \\ THE COURT OF JUSTICE OF THE EUROPEAN UNION \\ REFERRED BY ITALIAN CORTE COSTITUZIONALE, \\ SPANISH TRIBUNAL CONSTITUCIONAL, AND FRENCH CONSEIL CONSTITUTIONNEL
}

\begin{abstract}
The article concerns the issue of constitutional courts' preliminary references to the $\mathrm{CJ}$. So far only a few centralized constitutional courts have accepted raising the preliminary reference to the CJ. Three of them are courts which initially had denied such possibility, but later changed their minds: Italian Corte Costitutionale (the Italian Constitutional Court; further: ICC); Spanish Tribunal Constitucional (the Spanish Constitutional Tribunal, further: SCT) and French Conseil Constitutionell (the French Constitutional Council; further: FCC). The first reference addressed to the ECJ by ICC came after more than a decade of explicit denial of having the status of a court in the meaning of the current Article 267(3) TFUE. The change of the ICC's position towards the preliminary ruling procedure was based on the juxtaposition of two ways in which a constitutional review proceeding may be initiated in the Italian legal system: via incidentale and via principale. The SCT denied its status as a court in the meaning of Article 267(3) TFUE till 2011. The change of the SCT's position, in contrast to the ICC case was not followed by any in-depth argumentation favouring such "judicial volt". The FCC for the first time referred to the CJ in 2013. The profound change in the FCC's attitude towards EU law was triggered by the introduction of Priority Preliminary Question on Constitutionality proceedings (QPC) in 2008.
\end{abstract}

\section{Keywords}

Constitutional courts - preliminary ruling procedure - judicial review - Italian Corte Costituzionale - Spanish Tribunal Constitucional - French Conseil Constitutionnel

\footnotetext{
An associate professor (Chair of Constitutional Law, Faculty of Law and Administration, Nicolaus Copernicus University in Toruń) and a legal clerk (judge assistant) of the Constitutional Tribunal's Office. Her research interests focus on comparative aspects of constitutional review and the relationship between national constitutional law and EU law.
} 


\section{INTRODUCTORY REMARKS}

The preliminary ruling procedure provided for in Article 267 of the Treaty on the Functioning of the European Union (TFEU) has an immense impact on the harmonious development of EU law and the way in which national courts and EU courts interact and communicate. The main purpose of the preliminary ruling procedure is to prevent the occurrence within the Community of divergences in judicial decisions on questions of Community (UE) law, ensuring uniform interpretation of EU legal provisions across the 28 Member States. The procedure has provided a platform for the Court of Justice of the European Union (further: the CJ or ECJ) to deliver seminal judgments that have defined the relationship between the national and EU legal systems, among others, to develop fundamental principles of EU law, including direct effect, indirect effect (i.e. the interpretation of national law in line with directives) and primacy ${ }^{1}$. Therefore, it might be considered as one of the the most important aspects of the EU judicial system.

Under Article 267(2) of the TFUE the national court has discretion to refer a case if it considers that a decision on a question of EU law is necessary. However under Article 267(3), there is an obligation to refer a case concerning a question of EU law by any national court or tribunal against whose decision there is no judicial remedy. The broad interpretation of the term "court" used in Article 267 TFUE leads to the conclusion that a constitutional court may also be considered as a court in the meaning of Article 267(3) TFUE2

So far only a few centralized constitutional courts have accepted the raising of the preliminary reference to the CJEU (Belgian Constitutional Court, Austrian Constitutional Court, Lithuanian Constitutional Court, Italian Constitutional Court, Spanish Constitutional Tribunal and French

\footnotetext{
1 A. Norberg, Preliminary Rulings and the Co-operation Between National and European Courts, Lund: University of Lund 2006, p. 16.

2 Further on this issue, see: K. Wójtowicz, Sady konstytucyjne wobec prawa Unii Europejskiej [Constitutional Courts and the European Union Law], Warszawa: Biuro Trybunału Konstytucyjnego 2012, p. 129; A. Kustra, Sady konstytucyjna a procedura prejudycjalna przed Trybunatem Sprawiedliwości Unii Europejskiej [Constitutional Courts and the Preliminary Ruling Procedure Before the Court of Justice of the European Union], Przegląd Sejmowy [The Sejm Review] 2012, issue 4, p. 77.
} 
Constitutional Council) 3 . Three of them are courts which initially denied such a possibility, but later changed their mind and entered a preliminary ruling procedure. This paper aims to analyze the systemic factors which lead constitutional courts to deny their status of a court within the meaning of Article 267(3) of the TFUE, to present decisions in which the former position towards preliminary procedure was revised and to search for reasons that might have favoured change of mind.

\section{THE ITALIAN CORTE CONSTITUTIONALE}

The first reference addressed to the ECJ by Corte Costituzionale (the Italian Constitutional Court; further: ICC) came after more than a decade of explicit denial of having the status of a court within the meaning of the current Article 267(3) TFUE. For the first time the ICC expressed such view in the decision of 29 December 1995 (No. 536/1995) 4 . The case was initiated in via incidentale proceedings. In the course of an action brought by Messagero Servizi and Others, challenging an action of the Office of Registry imposing mortgage and land registry taxes, as well as capital duty, attributable to an increase in the company's capital by means of an acquisition, inter alia, of real estate, the Revenue Commission of Padua raised the incidental issue of the constitutional legitimacy of certain provisions of Italian tax law from the standpoint of Article 76 of the Constitution, to the extent that those provisions failed to provide for exemption from duty in such circumstances as were required by ECC Directive 69/335 of 17 July 1969 concerning indirect taxes on the raising of capital.

The ICC decided that the case was inadmissible and stated that it was not its task to provide an interpretation on Community norms, unless it is possible to do so on the basis of "clear evidence" or to resolve

3 Further on this issue, see: Wójtowicz, supra note 2, p. 129; Kustra, supra note 2, p. 77.

4 See: G. Martinico, Preliminary Reference and Constitutional Courts: Are We in the Mood for Dialogue?, Tilsburg Institute of Comparative and Transnational Law Working Paper 2009, no. 10, p. 11; electronic copy available at: https://ssrn.com/abstract+1483664 [last accessed: 16.12.2013]. Further on the issue of ICC's previous case-law concerning the preliminary ruling procedure, see: M. Dani, Tracking Judicial Dialogue - The Scope for Preliminary Rulings from the Italian Constitutional Court, The Jean Monnet Working Paper 2008, no. 10, pp. 5-12, electronic copy available at: www.JeanMonnetProgram.org [last accessed: 15.12.2013]. 
irreconcilable differences in interpretation in relation to those norms. The ICC indicated that in such a case it is necessary to refer the matter to the ECJ for an interpretation which is binding on all Member States. However, it also stated that the preliminary question cannot be referred by the ICC, since it essentially exercises the function of a constitutional review, ultimately guaranteeing the Observance of the Constitution of the Republic by the constitutional organs of the State and the Regions ${ }^{5}$.

The ICC claimed that it is impossible to recognized it as a "national jurisdiction" within the meaning of the previous Article 177 EC Treaty because the differences in the role performed by the ICC, which cannot truly be regarded as either an ordinary or a special judicial organ, are profound and without precedent in the Italian judicial system. The ICC indicated that that fact is well understood and historically established. It also claimed that it is for the judge seized of the case, once he has identified an issue of constitutional legitimacy based on a conflict between a norm of Community law and provisions of national law, in the absence of a specific precedent decision on the point by the ECJ, to make a reference to the $\mathrm{ECJ}^{6}$.

The precedent decision in which the ICC changed its mind concerning the preliminary procedure, concerned the constitutionality of Articles 2, 3 and 4 of the Regional Law of Sardinia no. 5 of 11th May 2006, (further RL 4/2006) both in the original version and in the version amended by the Regional Law of Sardinia no. 2 of 29th May 2007 (further RL 2/2007) as well as the constitutionality of RL 2/2007 itself. The challenged provisions were part of a wider tax reform promoted by the executive of the Sardinia Region and implemented by its regional legislative council. The aim of the reform was to create a policy designed to increase the fiscal pressure on those activities carried out by non-resident subjects on the territory of the Region, that are connected, in principle, with some form od economic exploitation of Sardinia's tourism attractiveness

\footnotetext{
5 See: K. Doktór-Bindas, Wptyw prawa Unii Europejskiej na system prawa Republiki Wtoskiej [The Influence of European Union Law on the Legal System of the Republic of Italy], Warszawa: Wydawnictwo Sejmowe 2013, pp. 247-248.

6 See: A. Oppenheimer (ed.), The Relationship Between European Community Law and National Law: The Cases, vol. 2, Cambridge: Cambridge University Press 2003, pp. 379-380.
} 
(so called "luxury taxes")7. Articles 2, 3 and 4 of the RL 4/2006 levied several regional taxes, respectively, on the added value of real estate properties used as second houses, on second houses used for tourism purposes, and on the supply of aircraft and pleasure boat services. Article 5 of the RL 2/2007 instead provided for a regional residence tax, levied upon every person - who is not registered as a resident with the municipal register - spending some time in Sardinia during the summer period (from 15 June to September 15$)^{8}$.

The provisions were challenged in via principale by the Italian Council of Ministers under multiple standards of review, both constitutional as well as regional and international ${ }^{9}$.

What is significant for the issue of the preliminary ruling procedure is the fact, that Article 4 of the RL 4/2006 was challenged under not only constitutional, but also - indirectly - Community law standards. The provision set a tax on planes and boats (not including cruise ferries, boats used in sports competitions, and boats spending the whole year in Sardinia's harbours). This tax is levied from June $1^{\text {st }}$ to $30^{\text {th }}$ September, and its payment was due in the case of each call made in regional airports for the purpose of the transport of individuals and yearly by the owner of any boat larger then 14 meters who intended to make a call at any harbour or mooring point placed on the territory of the Region. The Council of Ministers claimed that it violated Article 117 para 1 of the Constitution in relation to the provisions of the EC Treaty. According to the plaintiff, the provision was in conflict with Article 49 EC Treaty (regarding freedom of services), Article 81 in connection with Article 3 and Article 10 EC Treaty (aimed at protecting competition) and Article 87 EC Treaty (regarding the prohibition of state aids) ${ }^{10}$.

\footnotetext{
7 See: F. Fontanelli, G. Martinico, Cooperative Anatgonists. The Italian Constitutional Court and the Preliminary Reference: Are We Dealing With a Turning Point?, Eric Stein Working Paper 2008, no. 5, p. 7, electronic copy available at: https://www.ericsteinpapers.eu [last accessed: 13.12.2013].

8 Fontnelli, Martinico, supra note 6, p. 7.

9 See further on the issue: Z. Witkowski, Ustrój konstytucyjny wspótczesnych Włoch w aktualnej fazie jego przemian 1989-2004 [Constitutional System of Modern Italy in the Stage of Its Changes 1989-2004], Toruń: TNOiK 2004, p. 385.

10 Fontanelli, Martinico, supra note 6, p. 8.
} 
While the Council of Ministers claimed that the provision was unconstitutional since it violates the aforementioned EC Treaty provisions, the Region of Sardinia stated that those allegations were groundless. In the Region's view, the right interpretation of the EC Treaty provisions makes them compatible with the challenged provision of the RL 4/2006. However, the only institution which can assess a binding interpretation of the Community (EU) law is the ECJ. Therefore, the opinion of the ECJ seemed to be the only decisive element for the constitutionality question before the ICC11.

The ICC faced the problem of whether the primary EU law can be invoked as an indirect standard of constitutional review via the application of Article 117 para 1 of the Constitution and how it should treat such an interposed standard of review in the framework of the proceeding initiated in via principale ${ }^{12}$.

The change of the ICC's position towards the preliminary ruling procedure was based on the juxtaposition of two ways in which the constitutional review proceeding may be initiated in the Italian legal system. While the former case-law of the ICC defining its status as a Court within the meaning of Article 267(3) TFUE concerned the proceedings initiated in via incidentale (by a legal question of a court), the considered case was initiated by the Council of Ministers in via principale. The ICC claimed that there is a significant difference between the two proceedings. The court a quo in via inicidentale proceedings must first verify the consistency between the provision of national law and the Community law and therefore it is obliged to use the preliminary referral to the ECJ if there is any doubt o the interpretation of the Community law). Therefore the court a quo shall initiate the constitutional review proceeding only if it deems that an incompliance between a national law provision and the Italian Constitution exists. On the contrary, in via principale proceedings the ICC is the only judicial body involved in the review of a domestic provision allegedly in conflict with the UE law. Therefore the ICC, when facing a doubt on the EU law interpretation in the case

11 Ibidem.

12 Doktór-Bindas, supra note 5, p. 241. 
brought in via principale proceedings, cannot deny its status as a court in the meaning of Article 267(3) of the TFUE ${ }^{13}$.

In the analyzed case the ICC by order No. 103/2008 of 13 February 2008 decided to refer to the ECJ 4 preliminary questions:

1) Is Article $49 \mathrm{EC}$ to be interpreted as precluding the application of a rule, such as that laid down in Article 4 of RL No 4/2006, under which the regional tax on stopovers for tourist purposes by aircraft is levied only on undertakings operating aircraft which they use for the transport of persons in the course of "general business aviation" activities, which have their tax domicile outside the territory of the Region of Sardinia?

2) Does Article 4 of RL No 4/2006, by providing for the imposition of the regional tax on stopovers for tourist purposes by aircraft only on undertakings operating aircraft which they use for the transport of persons in the course of "general business aviation" activities, which have their tax domicile outside the territory of the Region of Sardinia, constitute, within the meaning of Article 87 EC, State aid to undertakings carrying on the same activities which have their tax domicile in the Region of Sardinia?

3) Is Article $49 \mathrm{EC}$ to be interpreted as precluding the application of a rule, such as that laid down in Article 4 of RL 4/2006, under which the regional tax on stopovers for tourist purposes by recreational craft is levied only on undertakings operating recreational craft, which have their tax domicile outside the territory of the Region of Sardinia and whose commercial operations involve making such craft available to third parties?

4) Does Article 4 of RL No 4/2006, by providing for the imposition of the regional tax on stopovers for tourist purposes by recreational craft only on undertakings operating recreational craft, which have their tax domicile outside the territory of the Region of Sardinia and whose commercial operations consist in making such craft available to third parties constitute, within the meaning of Article $87 \mathrm{EC}$, give State aid to undertakings carrying

13 Fontanelli, Martinico, supra note 6, pp. 9-10; Doktór-Bindas, supra note 5, p. 253. 
on the same activities which have their tax domicile in the Region of Sardinia?

The ECJ ruled in the judgment of 17 November 2009 case C-169/08 that:

Article 49 EC must be interpreted as precluding tax legislation, adopted by a regional authority, such as that provided for under Article 4 of RL 4/2006 (Miscellaneous provisions on revenue, reclassification of costs, social policy and development) as amended by Article 3(3) of RL 2/2007 (Provisions for the preparation of the annual and long-term budget of the Region - 2007 Finance Law), which establishes a regional tax on stopovers for tourist purposes by aircraft used for the private transport of persons, or by recreational craft, to be imposed only on natural and legal persons whose tax domicile is outside the territory of the region.

Article 87(1) EC must be interpreted as meaning that tax legislation, adopted by a regional authority, which establishes a tax on stopovers, such as that at issue in the main proceedings, to be imposed only on natural and legal persons whose tax domicile is outside the territory of the region, constitutes a State aid measure in favour of undertakings established in that territory.

The ICC took into account the judgment of the ECJ in Case C-169/08 and in the judgment of 17 June 2010 (No. 216/2010) declared the unconstitutionality of the challenged Article 4 of RL 4/2006, as amended by Article 3, para. 3 of RL 2/2007. The ICC decided to give the judgment a "revival" effect provided for in Article 27 of the Act of 11 March 1953 on the Functioning of the Constitutional Court. Therefore, the challenged provision regained its previous wording.

There were several factors which had impact on the ICC's change of mind. Not without significance were certainly both the jurisdiction of other constitutional courts that had already referred a preliminary question as well as "camouflaged" in these decisions Traghetti and Köbler pressure from the ECJ, which indicated that the lack of a ruling by the court of last instance may result in liability for damages for a Member ${ }^{14}$.

Another factor that influenced the shift from the view expressed in 1995 was the constitutional reform of 2001 which, inter alia, changed

14 Martinico, supra note 4, pp. 15-16. 
the wording of Article 117 of the Italian constitution. In Italy, since the accession to the Communities and until 2001, the only constitutional "provision" of an integration function was Article 11. According to it: "Italy rejects war as an instrument of aggression against the freedom of other peoples and as a means for the settlement of international disputes. Italy agrees, on conditions of equality with other States, to the limitations of sovereignty that may be necessary to a world order ensuring peace and justice among the Nations. Italy promotes and encourages international organizations furthering such ends". On the contrary, Article 117, which regulates the division of legislative powers between the State and the Regions currently expressis verbis refers to the EU law. It states in the first sentence, that "the legislative powers shall be vested in the State and the Regions in compliance with the Constitution and with the constraints deriving from EU legislation and international obligations". Such wording of Article 117 means that at present it is difficult to conclude that EU law is an inadequate standard of review in the constitutional review proceedings ${ }^{15}$.

It should be emphasized that the ICC has changed its previous attitude towards preliminary ruling procedure presenting the shift as the next stage of a consistent court's jurisprudence, and not a revolution in the previous case-law. Such approach was possible because of the aforementioned juxtaposition of two ways of initiating the constitutional review proceedings in the Italian legal system: via principale and via incidentale ${ }^{16}$.

\section{THE SPANISH TRIBUNAL CONSTITUCIONAL}

The Spanish Tribunal Constitucional (Constitutional Tribunal; further: SCT) denied its status as a court in the meaning of Article 267(3) TFUE till 2011. The SCT's argumentation was rather similar to the ICC's reasoning in the years 1995-2008. The SCT claimed that it is the ordinary courts' task to review the compliance of national legislation with Community law standards. Such an attitude also meant that the SCT refused to recognize EU law as an adequate standard of review

\footnotetext{
15 Ibidem, pp. 9-10.

16 Kustra, supra note 2, p. 90.
} 
in constitutional review proceedings. The position was presented widely in SCT's judgment of 13 December 1993, ref. STC 372/199317.

Unlike the ICC, the SCT did not build its view on the finding that it does not meet the characteristics of a court in the meaning of Article 267(3) of the TFUE. The position resulted rather from the adoption of a secure concept of "separate fields of cognitions" of the SCT and the ECJ18.

The SCT changed its mind in the order of 9 June 2011, ref. ATC 86/2011, and referred to CJ three preliminary questions ${ }^{19}$.

It should be noted that the change of the SCT's position, in contrast to the ICC case, was not followed by any in-depth argumentation favouring such a "judicial volt" 20 .

Moreover, the case in which the preliminary questions were referred was very similar to a previously decided one: No. STC 199/2009. Both - case 199/2009 (ruled in judgment of 28 September 2009) and case ATC 86/2011, in which the SCT decided to change its view on preliminary ruling procedure, were related to the implementation of the Council Framework Decision 2002/584/JHA of 13 June 2002 on the European arrest warrant and the surrender procedures between Member States (further: EAW Framework Decision) recently amended by Council Framework Decision 2009/299/JHA of 26 February 2009 (EAW Amendment Frameweork Decision 2009). Both cases concerned the constitutionality of the execution of an EAW against a person convicted in absentia in another EU Member State. In case STC 199/2009, the Audiencia National (Spanish Supreme Court) agreed to the surrender of a British citizen to the Romanian authorities on the basis of an EAW, in order to serve his four-year prison sentence for the offense of sexual exploitation

17 K. Zaradkiewicz (ed.), Relacje między prawem konstytucyjnym a prawem UE w orzecznictwie sadów konstytucyjnych państw Unii Europejskiej [Relationship Between Domestic Constitutional Law and EU Law in the Jurisdiction of Constitutional Courts of EU Member States], Warszawa: Biuro Trybunału Konstytucyjnego 2011, pp. 94-95.

18 Kustra, supra note 2, p. 91; Zaradkiewicz (ed.), supra note 17, pp. 94-95.

19 See: A.T. Pérez, Spanish Constitutional Court, Constitutional Dialogue on the European Arrest Warrant: The Spanish Constitutional Court Knocking on Luxembourg's Door; the Spanish Constitutional Court's Order of 9 June 2011, ATC 86/2011, European Constitutional Law Review 2012, issue 1, pp. 105-127.

20 Kustra, supra note 2, p. 92. 
of minors. Both the proceedings at the court of first instance and on appeal in Romania took place in the absence of the accused person. His defense was carried out by a lawyer of his choice. The SCT in a judgment of 29 September 2009 awarded the applicant partial constitutional protection to guarantee his constitutional right to a fair trial and reversed the Audiencia Nacional judgment. Concominantly, the SCT held that the surrender of the accused person to another Member State on the grounds of the EAW deprived him of the possibility of an appeal against the sentence. This consequently meant the violation of the applicant's right to a fair trial. The SCT indicated that the presence of counsel at the hearing could not be compared with the personal attendance of the accused. Therefore, the SCT held that only the physical presence of the accused at the trial can fully guarantee their right to defense ${ }^{21}$.

Case ATC 86/2011 in which the SCT referred for the first time to the CJ concerned an Italian citizen - Mr. Melloni - who was convicted in Italy in absentia and sentenced to ten years imprisonment for the offense of apparent bankruptcy. During the proceedings before the Italian authorities Mr. Melloni was represented by two lawyers of his choice. On 8 June 2004 the Court of Appeal in Bologna issued the EAW against the accused. On 1 August 2008 Mr. Melloni was arrested in Spain. On 12 December 2008 the competent Spanish authority - Audiencia National - decided to execute the EAW on the detainee and surrender him to the Italian authorities. It should be noted that this decision was made before the adoption of the abovementioned judgment of SCT in case STC 199/2009. Audiencia National found that although the Italian court's judgment was rendered in absentia Mr. Melloni knew about the lawsuit and voluntarily chose not to appear in court. In addition, he chose two lawyers who defended him. Mr. Melloni filed a constitutional complaint to SCT (recurso de amparo). He alleged infringement of the absolute requirements deriving from the right to a fair trial proclaimed in Article 24(2) of the Spanish constitution. In his submission, the very essence of a fair trial had been violated in such a way as to undermine human dignity, as a result of allowing surrender to countries which,

21 Martinico, supra note 4, pp. 98-99. 
in the event of very serious offences, validate findings of guilt made in absentia, without making surrender subject to the condition that the convicted party is able to challenge them in order to safeguard his rights of defence ${ }^{22}$.

By order of 18 September 2008, the First Section of the SCT acknowledged that the recurso de amparo was admissible and suspended enforcement of the order of 12 September 2008. By order of 1 March 2011, the Plenary Chamber of the SCT decided, on a proposal from the First Section, that it would itself examine the recurso de amparo.

The SCT pointed out that in the judgment 91/2000 of 30 March 2000 it recognised that the binding nature of fundamental rights when applied "externally" is attenuated, since only the most basic or elementary requirements may be linked to Article 24 of the Spanish Constitution and give rise to a finding of "indirect" unconstitutionality. Nevertheless, a decision of the Spanish judicial authorities to consent to extradition to countries which, in cases of very serious offences, allow convictions in absentia without making the surrender conditional upon the convicted party being able to challenge the same in order to safeguard his rights of defence, gives rise to an "indirect" infringement of the requirements deriving from the right to a fair trial, in that such a decision undermines the essence of a fair trial in a way which affects human dignity ${ }^{23}$.

According to the SCT, the difficulty arose from the fact that EAW Amendment Framework Decision 2009 repealed Article 5(1) of the EAW Framework Decision and introduced therein a new Article 4a. Article 4a precludes a refusal to execute the EAW issued for the purpose of executing a custodial sentence or a detention order if the person did not appear in person at the trial resulting in the decision where the person concerned, being aware of the scheduled trial, had given a mandate to a legal counsellor, who was either appointed by the person concerned or by the State, to defend him or her at the trial, and he or she was indeed defended by that counsel at the trial. For the SCT the question therefore arose as to whether the current wording of the EAW Framework Decision

\footnotetext{
22 Pérez, supra note 16, p. 107.

23 See point 21 of the CJ judgment of 26.02.2013, case C-399/11 Melloni.
} 
precludes the Spanish courts from making surrender of $\mathrm{Mr}$ Melloni conditional on the right to have the conviction in question reviewed ${ }^{24}$.

In the light of those considerations, the SCT decided to stay the proceedings and to refer the three questions to the $\mathrm{CJ}$ for a preliminary ruling:

1) Must Article $4 \mathrm{a}(1)$ of the EAW Framework Decision, as inserted by the EAW Amendment Framework Decision, be interpreted as precluding national judicial authorities, in the circumstances specified in that provision, from making the execution of an EAW conditional upon the conviction in question being open to review, in order to guarantee the rights of defence of the person requested under the warrant?

2) In the event of the first question being answered in the affirmative, is Article $4 \mathrm{a}(1)$ of an EAW Framework Decision compatible with the requirements deriving from the right to an effective judicial remedy and to a fair trial, provided for in Article 47 of the Charter of Fundamental Rights; further: the Charter, and from the rights of defence guaranteed under Article 48(2) of the Charter?

$3)$ In the event of the second question being answered in the affirmative, does Article 53 of the Charter, interpreted schematically in conjunction with the rights recognised under Articles 47 and 48 of the Charter, allow a Member State to make the surrender of a person convicted in absentia conditional upon the conviction being open to review in the requesting State, thus affording those rights a greater level of protection than that deriving from EU law, in order to avoid an interpretation which restricts or adversely affects a fundamental right recognised by the constitution of the first-mentioned Member State?

As mentioned, the SCT did not provide extensive argumentation favouring the change of existing jurisprudence. Nor did the SCT give up the concept of separate fields of cognition, which is the essential element of the thesis that EU law cannot be recalled as a direct standard of review in proceedings before the SCT. This time however, the SCT noticed that

24 See point 23 of the CJ judgment of 26.02.2013, case C-399/11 Melloni. 
sometimes, even if EU law is not applied directly in the proceedings, it may be relevant to the interpretation of constitutional standards of review ${ }^{25}$.

A.T. Pérez when analyzing the background of case ATC 86/2011 indicates several hypothetical factors of the judicial shift in relation to preliminary ruling procedure. Firstly, from a systemic point of view, the Lisbon Treaty had a certain influence on the modification of the SCT's position. The After-Lisbon Article 4(2) TUE replaced a more modestly formulated provision of Article 6(3) of the pre-Lisbon Treaty. The provision is now situated between a provision laying down the principle of conferral (according to which competences not conferred on the Union in the Treaties remain with the Member States) and that laying down the principle of sincere cooperation. Currently Article 4(2) TUE explicitly stays that: "The Union shall respect the equality of Member States before the Treaties as well as their national identities, inherent in their fundamental structures, political and constitutional, inclusive of regional and local self-government. It shall respect their essential State functions, including ensuring the territorial integrity of the State, maintaining law and order, and safeguarding national security. In particular, national security remains the sole responsibility of each Member State", and the SCT stated in the declaration of $1 / 2004$ that the respect for constitutional rights and freedoms should be considered as an absolute boundary of the EU integration process. On the other hand, Lisbon Treaty abolished the previous three-pillar structure of the EU, thus enhancing the importance of the EU legislation in the framework of the previous second and third pillar. Certainly an important impulse for the considered judicial shift was also the amendment of the EAW Framework Decision from 2009, which highlighted the already previously perceived conflict between the principle of mutual recognition in criminal matters and the constitutional guarantees of the right to a fair trial. Perhaps the CJ judgments in aforementioned cases Köbler and Tragetti also had an impact on SCT's decision.

If Mr Melloni's constitutional complaint was ruled on by the SCT in the same way as in the case of 2009, it could cause Spain's liability for breach of the Framework Decision on the EAW. Finally it is quite

25 See: Kustra, supra note 2, p. 94. 
probable that change in the $\mathrm{SCT}^{\prime}$ s position concerning preliminary ruling procedure was also influenced by other factors such as the "good example" of other constitutional courts (including the ICC) or the choice of four new judges of the SCT26.

The CJ decided the case Melloni in the judgment of 26 February 2013. The CJ held that the right of the accused to appear personally at the hearing is an essential component of the right to a fair trial, but this right is not absolute. According to the $\mathrm{CJ}$ there is no infringement of the right to a fair trial, even if the accused did not appear in person, if only the person convicted in absentia was aware, in due time, of the scheduled trial and was informed that a decision could be handed down if he did not appear for the trial or, being aware of the scheduled trial, gave a mandate to a legal counsellor to defend him at the trial. The CJ also stressed that such an interpretation is consistent with the European Court of Human Rights case law concerning the interpretation of Article 6 paragraph 1 and 3 of the European Convention on Human Rights.

In answer to the second question the CJ stated that Article $4 a(1)(a)$ and (b) of the EAW Framework Decision lays down the circumstances in which the person concerned must be deemed to have waived, voluntarily and unambiguously, his right to be present at his trial, with the result that the execution of a EAW issued for the purposes of executing the sentence of a person convicted in absentia cannot be made subject to the condition that that person may claim the benefit of a retrial at which he is present in the issuing Member State. This is so either where, as referred to in Article $4 \mathrm{a}(1)(\mathrm{a})$, the person did not appear in person at the trial despite having been summoned in person or officially informed of the scheduled date and place of the trial or, as referred to in Article $4 \mathrm{a}(1)(\mathrm{b})$, the person, being aware of the scheduled trial, deliberately chose to be represented by legal counsel instead of appearing in person. Article $4 \mathrm{a}(1)(\mathrm{c})$ and (d) refer to circumstances where the executing judicial authority is required to execute the EAW, even though the person concerned is entitled to a retrial, because the arrest warrant states that the person concerned either did not ask for a retrial or that he will be expressly informed of his right to a retrial.

26 Pérez, supra note 16, pp. 121-123. 
In the light of the foregoing, the CJ ruled that Article $4 \mathrm{a}(1)$ of the EAW Framework Decision does not disregard either the right to an effective judicial remedy and to a fair trial or the rights to the defence guaranteed by Articles 47 and 48(2) of the Charter respectively.

In response to the third question the $\mathrm{CJ}$ indicated that by that question the national court asked, in essence, whether Article 53 of the Charter must be interpreted as allowing the executing Member State to make the surrender of a person convicted in absentia conditional upon the conviction being open to review in the issuing Member State, in order to avoid an adverse effect on the right to a fair trial and the rights of the defence guaranteed by its constitution. The CJ stated that such an interpretation would give general authorisation to a Member State to apply the standard of protection of fundamental rights guaranteed by its constitution when that standard is higher than that deriving from the Charter and, where necessary, to give it priority over the application of provisions of EU law. Such an interpretation would, in particular, allow a Member State to make the execution of a European arrest warrant issued for the purposes of executing a sentence rendered in absentia subject to conditions intended to avoid an interpretation which restricts or adversely affects fundamental rights recognised by its constitution, even though the application of such conditions is not allowed under Article 4a(1) of the EAW Framework Decision. Therefore, the CJ stated that such an interpretation of Article 53 of the Charter cannot be accepted. The CJ pointed out that such an interpretation of Article 53 of the Charter would undermine the principle of the primacy of EU law inasmuch as it would allow a Member State to disapply EU legal rules which are fully in compliance with the Charter where they infringe the fundamental rights guaranteed by that State's constitution. Consequently, the CJ ruled that Article 53 of the Charter must be interpreted as not allowing a Member State to make the surrender of a person convicted in absentia conditional upon the conviction being open to review in the issuing Member State, in order to avoid an adverse effect on the right to a fair trial and the rights of the defence guaranteed by its constitution ${ }^{27}$.

27 See: points 55-64 of the CJ judgment of 26.02.2013, C-399/11 Melloni. 
The Melloni case clearly shows the rather wide field of probable collisions concerning standards of individual rights' protection guaranteed by legal systems of: Member States, EU, and the Council of Europe. The CJ judgment in the presented case indicates that even if the national constitution provides a higher level of fundamental rights protection it is not effective if it precludes the EU law effectiveness in the national legal system. Therefore a Member State can not provide a lower standard of protection of fundamental rights than the one guaranteed in the Charter and the CJ jurisdiction, but even if it provides a higher level, it will be effective only if it does not undermine the principle of uniform application of UE law ${ }^{28}$.

\section{THE FRENCH CONSEIL CONSTITUTIONNEL}

The French Conseil Constitutionnel (Constitutional Council; further: FCC), for the first time referred to the CJ in decision issued on 4 April 2013. The FCC requested the CJ's interpretation in order to properly answer a Priority Preliminary Question on Constitutionality (further QPC) filled by Cour de Cassation (the Court of Cassation, further: the CC).

The decision was issued on following factual background. On 25 September 2012 the Crown Court at Maidstone issued an EAW against Mr Jérémy F. - a United Kingdom national - in connection with criminal proceedings brought against him for acts committed in the United Kingdom which could be classified in English law as child abduction, an offence for which the maximum sentence is seven years' imprisonment.

On being stopped and questioned in France on 28 September 2012, Mr Jérémy F. expressly stated on that date before the principal public prosecutor at the Cour d'appel de Bordeaux that he agreed to be surrendered to the judicial authorities of the United Kingdom, without, however, waiving the "speciality" principle. According to this principle a state wishing to prosecute a surrendered person for offences committed before his or her surrender, or extradite a surrendered person

28 See further on the issue: N. de Boer, Addressing Rights Divergences Under the Charter: Melloni. Case C-399/11, Stefano Melloni v. Ministerio Fiscal, Judgment of the Court (Grand Chamber) of 26 February 2013, nyr., Common Market Law Review 2013, vol. 50, pp. 1083-1104. 
to a third state, must, subject to certain exception, obtain the permission of the executing judicial authority. Such a request is made in the same form as an EAW and granted or refused using the same rules which determine whether surrender would be granted or refused. The principle of "specialty" is intended to ensure that a state cannot seek the surrender of a person for an extraditable offence whilst intending to prosecute that person for a non-extraditable offence once surrendered, or extradite the surrendered person to a third state for an offence which would not have been extraditable offence from the original executing state.

By the judgment of 4 October 2012, the indictment division of the Cour d'appel de Bordeaux ordered the surrender of Mr Jérémy F. to the judicial authorities of the United Kingdom for the purpose of the above-mentioned criminal proceedings. He was surrendered on 10 October 2012 and has been in custody in the United Kingdom since then.

On 22 October 2012 the principal public prosecutor at the Cour d'appel de Bordeaux received a request from the judicial authorities of the United Kingdom for the consent of the indictment division of that court to the prosecution of the applicant in the main proceedings for acts committed in the United Kingdom before his surrender which might constitute an offence other than that for which he had been surrendered. According to the United Kingdom judicial authorities, on the return of the girl who was the subject of the alleged abduction, she had stated that she had had sexual relations with the applicant in the main proceedings in the period from 1 July to 20 September 2012. As such acts could be classified in English law as the offence of sexual activity with a child under 16, for which the maximum sentence is 14 years' imprisonment, the judicial authorities therefore decided to prosecute him for that offence. The request from the United Kingdom judicial authorities was on 16 November 2012 embodied in an EAW referring to the offences which were the subject of the new prosecution. Following the hearing of 18 December 2012, the indictment division of the Cour d'appel de Bordeaux decided, by judgment of 15 January 2013, to give consent to the request to extend the surrender with a view to new criminal proceedings being brought against Mr Jérémy $\mathrm{F}$. for the acts of sexual activity with a child under 16 during the above-mentioned period. 
Mr Jérémy F. appealed to the CC against the judgment of 15 January 2013, and the CC referred to the FCC a priority question of constitutionality relating to Article 695-46 of the Code of Criminal Procedure, concerning in particular the principle of equality before the law and the right to an effective judicial remedy 29 .

In those circumstances, the FCC decided to stay the proceedings and to refer the following question to the $\mathrm{CJ}$ for a preliminary ruling: "Must Articles 27 and 28 of [the Framework Decision] be interpreted as precluding Member States from providing for an appeal suspending execution of the decision of the judicial authority which rules, within a period of 30 days from receipt of the request, in order either to consent to the prosecution, sentencing, or detention with a view to the carrying out of a custodial sentence or detention order of a person for an offence committed prior to his surrender pursuant to a European arrest warrant, other than that for which he was surrendered, or to consent to the surrender of a person to a Member State other than the executing Member State, pursuant to a European arrest warrant issued for an offence committed prior to his surrender?" 30 .

The FCC applied also for a preliminary ruling to be dealt with under the urgent procedure pursuant to Article 23a of the Statute of the Court of Justice of the European Union and Article 107 of the Court's Rules of Procedure. As reasons for that application, the FCC indicated that both the three-month period within which it is required to rule on the priority question of constitutionality referred to it and the deprivation of liberty to which the applicant in the main proceedings is subject in the proceedings in which that question has been raised justify applying the urgent preliminary ruling procedure ${ }^{31}$.

The CJ granted the application for recognition of the urgency and answered the FCC's preliminary question in the judgment of 30 May 2013, Case C-168/13 Jeremy F. against the Prime Minister. The CC ruled that: "Articles 27(4) and 28(3)(c) of the EAW Framework Decision, as amended

\footnotetext{
29 See: points $19-27$ of the CJ judgment of 30.05.2013, case C-168/13 Jeremy F v. Prime Minister.

30 See: point 27 of the CJ judgment of 30.05.2013, case C-168/13 Jeremy F. v. Prime Minister.

31 See: points 28-32 of the CJ judgment of 30.05.2013, case C-168/13, Jeremy F. v. Prime Minister.
} 
by the Amendment Framework Decision, must be interpreted as not precluding Member States from providing for an appeal suspending execution of the decision of the judicial authority which rules, within 30 days from receipt of the request, on giving consent either to the prosecution, sentencing or detention with a view to the carrying out of a custodial sentence or detention order of a person for an offence committed prior to his surrender pursuant to an EAW, other than that for which he was surrendered, or to the surrender of a person to a Member State other than the executing Member State, pursuant to an EAW issued for an offence committed prior to his surrender, provided that the final decision is adopted within the time-limits laid down in Article 17 of the EAW Framework Decision" 32 .

The FCC in the judgment of 14 June 2013 took into account the interpretation of the EAW Framework Decision adopted in the CJ's judgment. The FCC decided that since the EAW Framework Decision does not prevent the submission by the person covered by the EAW appeal against a decision extending the scope of the EAW for offenses not covered by the original EAW (if it will be processed within 30 days of receipt of such request by the judicial authority of another Member State), the challenged provision remained within a Member State's discretion in the EAW Framework Decision implementation. In other words, the EAW Framework Decision, was not an act which in the case determined the diminuition of the constitutional standard of protection of individual rights. Hence, the FCC did not see any grounds for exclusion of the considered type of decision from the appealing procedure and ruled that the challenged provision was unconstitutional.

When analyzing the motives changes the position of the FCC towards preliminary ruling procedure, it should be noted that the FCC has traditionally refused to review the compatibility of national law with international law, including also and Community law (EU law). In a well-known decision regarding the Abortion Act $^{33}$ the FCC showed

\footnotetext{
32 See: point 76 of the CJ judgment of 30.05.2013, case C-168/13, Jeremy F. v. Prime Minister.

33 Ruling No. 74-54, 15.01.1975 (Law on Voluntary Termination of Pregnancy). See further on the issue: J.F. Colares, The Reality of EU-Conformity Review in France, College of Law Faculty Scholarship 2012, Paper 66, p. 12, electronic copy available at: http://surface.syr.edu/lawpub/66 [last accessed: 6.02.2014].
} 
that it had no intention of establishing any relationship between domestic constitutional law and international law or EU law. The FCC stated that "a law violating a treaty does not necessarily violate the Constitution"34.

Consequently, ensuring the effectiveness of EU law in France was the domain of ordinary and administrative courts ${ }^{35}$.

The radicalism of the FCC's view has been softened with the perceived need to ensure the proper implementation of Community Directives ${ }^{36}$. In the decision of 10 June 2004 (Act Call No. 2004-496 DC) the FCC acknowledged the constitutional value of the obligation to incorporate European directives into national law. In the decision of 30 November 2006 (Act Call No. 2006-543 DC), the FCC went further and claimed that a statutory law was clearly incompatible with a Community Directive. Formally, such a review is a constitutional review, where the standard of review is formed by constitutional provisions concerning the international and EU obligations of France. An indirect standard of review is however the EU Directive itself ${ }^{37}$.

The decisions of 10 June 2004 and 30 November 2006 were first steps towards acknowledgement of the EU law as a standard in the constitutional review proceedings. Already at this point, the FCC could hypothetically refer a preliminary question to the $\mathrm{CJ}$ in a case concerning the constitutionality of law implementing the EU Directive, if there was any doubt as to the interpretation of the Directive. However,

34 Cons. 5 of the FCC judgment.

35 See further on the issue: O. Pollicino, The Conseil d'Etat and the Relationship Between French Internal Law After Arcelor: Has Something Really Changed?, Common Market Law Review 2008, vol. 45 , p. 1524.

36 See further on the issue: K. Wójtowicz, Francuski model kontroli konstytucyjności prawa krajowego implementujacego prawo wspólnotowe [French Model of Judicial Review of Domestic Law Implementing the Community Law], [in:] P. Tuleja, M. Florczak-Wątor, S. Kubas (eds), Prawa człowieka. Społeczeństwo obywatelskie. Państwo prawa. Księga jubileuszowa dedykowana profesorowi Pawłowi Sarneckiemu [Human Rights. Civil Society. Rule of Law. The Anniversary Volume Dedicated Professor Pawet Sarnecki], Warszawa: Wydawnictwo Sejmowe 2010, pp. 220-228; K. Kubuj, Implementacja prawa wspólnotowego na tle doświadczeń Francji [Implementation of Community Law Against French Backdrop], Warszawa: Scholar 2006, p. 88.

37 Martinico, supra note 4, pp. 73-74; K. Wójtowicz, Glosa do orzeczenia francuskiej Rady Konstytucyjnej z dnia 10 czerwca 2004 r. (sygn. 2004-496 DC) [Gloss to the Decision of the French Constitutional Council of June 10, 2004 (Act Call No. 2004-496 DC)], Przegląd Sejmowy [The Sejm Review] 2005, issue 1, pp. 158-165; K. Wojtyczek, Europeizacja Konstytucji $V$ Republiki Francuskiej [Europeanization of the Constitution of the $5^{\text {th }}$ Republic], Przeglad Sejmowy [The Sejm Review] 2008, issue 6, p. 148. 
the FCC still did not recognized itself as the court within the meaning of the current Article 267(3) TFEU38.

Taking this position was definitely associated with the specificity of the French paradigm of constitutional review. Until 2008 the FCC's competences were limited to performance of a priori constitutional review (reviewing statute laws before their entry into force). Such limitation of powers meant that the constitutional review proceedings could be initiated only by eligible parties who submitted an application without any direct interrelatedness with a concrete case before a court (abstract mode of review). Such a constitutional arrangement meant that the FCC's powers were limited in comparison to other centralized constitutional courts. The limited scope of cognition enabled the FCC to avoid the problematic issue of EU law interpretation.

Therefore, the significant shift in the FCC's attitude towards EU law - Constitution relationship, was triggered by the introduction of QPC procedure in 2008. The constitutional provision that establishes a legal basis for this procedure is Article 61(1) of the Constitution, which was introduced by Constitutional Law No. 2008-724 of 23 July 2008 on the modernization of the institutions of the Fifth Republic. The aforementioned provision states that: "If, during proceedings in progress before a court of law, it is claimed that a legislative provision infringes the rights and freedoms guaranteed by the Constitution, the matter may be referred by the Conseil d'État or by the Cour de Cassation to the Constitutional Council which shall rule within a determined period. An Institutional Act shall determine the conditions for the application of the present article" ${ }^{\prime 39}$.

\footnotetext{
38 Martinico, supra note 4, pp. 73-74.

39 See further on the issue: A. Chmielarz, Rada konstytucyjna po zmianach konstytucyjnych $z$ lipca 2008 r. [Constitutional Council After Constitutional Amendments of 2008], Przegląd Sejmowy [The Sejm Review] 2010, issue 1, p. 135; V. Bernard, M.F.-R. Stéfanini, Reforma kontroli konstytucyjności prawa (refleksje na temat projektów artykułów 61-1 i 62 Konstytucji przedstawionych przez Komitet Balladura) [The Reform of the Constitutional Review (Reflections on the Drafts of Articles 61-1 and 62 of the Constitution Presented by the Balladur Committee], Przegląd Sejmowy [The Sejm Review] 2008, issue 6, p. 161; F. Fabbrini, Kelsen in Paris: France's Constitutional Reform and the Introduction of a A Posteriori Constitutional Review of Legislation, German Law Journal 2008, issue 10, p. 1297.
} 
The introduction of a posteriori constitutional review, which is institutionally interrelated to a concrete case pending before a court, meant a revolutionary change of the French paradigm of constitutional review.

The "allegation of unconstitutionality" in the QPC may be brought by any party to proceedings before the court and it is pre-verified by the highest judicial bodies (Council of State and the Court of Cassation). Consequently, the matters that are brought before the FCC are usually significant and often concern the fundamental problems of constitutional rights protection. Therefore the introduction of the QPC proceedings reinforced the FCC's position as an organ of constitutional rights protection. The application of the QPC procedure caused that FCC to see that the applied interpretation of constitutional rights and freedoms must be in compliance with EU law standards.

\section{FINAL REMARKS}

Significant shifts in the jurisprudence of three constitutional courts concerning the application of preliminary ruling procedure show that nowadays EU law increasingly becomes a benchmark in the process of constitutional adjudication. The constitutional court may refer to EU law in order to determine a "demarcation line" which separates the CJ and constitutional courts fields of cognition, but it may also apply the EU law while interpreting constitutional standards in compliance with EU law. International law and EU law standards nowadays heavily affect constitutional standards, sometimes determining their modification (elevation or diminuition). The presented decisions of ICC, SCT and FCC should be considered as parts of a discernible evolution of constitutional courts' approach towards both the constitutional status of EU law and the procedural cooperation with the CJ. As D. Sarmiento claimed in a comment on one of the recent SCT's judgments, constitutional courts are starting more and more actively to apply EU law, because they recognize that "the isolationism doctrine" is not in their interest in the long term. Cooperation with the CJ on a procedural niveau helps constitutional courts to effectively defend their political position vis-à-vis national courts, which sometimes use their "Community mandate" 
to weaken the constitutional courts' position $^{40}$. All three presented cases support this thesis.

\section{Post Scriptum}

On the $7^{\text {th }}$ of February 2014 German Bundesverfassungsgericht decided to use for the first time the preliminary ruling procedure. This salient decision means that at present already seven centralized constitutional courts have requested the $\mathrm{CJ}$ for preliminary ruling.

40 D. Sarmiento, Reinforcing the (Domestic) Constitutional Protection of Primacy of EU Law. Tribunal Constitutional (Spanish Constitutional Court), Judgment 145/2012 of 2 July 2012, Iberdrola v. Commisión Nacional de la Energía, Common Market Law Review 2013, vol. 50, p. 890. 
